Please do not remove this page

RMIT

UNIVERSITY

\title{
Why university education matters: Youth work and the Australian experience
}

Bessant, Judith; Emslie, Michael

https://researchrepository.rmit.edu.au/esploro/outputs/9921859575301341/filesAndLinks?institution=61RMIT_INST\&index=null

Bessant, J., \& Emslie, M. (2014). Why university education matters: Youth work and the Australian experience. Child \& Youth Services, 35(2), 137-151. https://doi.org/10.1080/0145935X.2014.924345

Document Version: Accepted Manuscript

Published Version: https://doi.org/10.1080/0145935X.2014.924345

Repository homepage: https://researchrepository.rmit.edu.au

Copyright (C) 2014 Taylor \& Francis Group, LLC.

Downloaded On 2023/04/26 20:07:31 +1000

Please do not remove this page 
Thank you for downloading this document from the RMIT Research Repository.

The RMIT Research Repository is an open access database showcasing the research outputs of RMIT University researchers.

RMIT Research Repository: http://researchbank.rmit.edu.au/

\section{Citation:}

Bessant, J and Emslie, M 2014, 'Why university education matters: Youth work and the Australian experience', Child \& Youth Services, vol. 35, no. 2, pp. 137-151.

See this record in the RMIT Research Repository at:

https://researchbank.rmit.edu.au/view/rmit:24727

Version: Accepted Manuscript

Copyright Statement:

(c) 2014 Taylor \& Francis Group, LLC.

\section{Link to Published Version:}

http://dx.doi.org/10.1080/0145935X.2014.924345 
Bessant, J. and Emslie, M. 2014. 'Why university education matters: Youth work and the Australian experience', Child and Youth Services, vol. 3, no. 2, pp. 37-151.

\begin{abstract}
In many countries youth work education in the university confronts a precarious future. Paradoxically, this takes place as the labour market is unable to meet demands for qualified practitioners. This article makes a case for further investment in university-based youth work education. While presenting labour demand and supply arguments, we also suggest that a good university education is important for producing graduates capable of becoming experts and good practitioners in the Aristotelian sense of the word. This entails the provision of learning opportunities to attain specialist knowledge, technical expertise and ethical capacities of the kind that distinguish youth work practice from other approaches to work with young people. Such an education also promotes the prospect that practitioners are able to develop a professional habitus that advances youth work as a discrete field of professional practice. While the material used in this article is Australian, we suggest there are sufficient commonalities between the Australian experience and many other countries for the arguments, findings and recommendations made here to have more general applicability.
\end{abstract}

\title{
Keywords
}

Youth work

Higher education

Fitness to practice

\section{Introduction}

Recent interventions by Australia's Department of Human Services (DHS) exemplify the kind of thinking that now characterises human services here and in many other countries. DHS says it wants to advance the government's 'social inclusion framework' by changing the way it offers services: 'many of our most basic transactions remain costly, labour intensive and time consuming' (DHS, 2011, p.3). This initiative is illustrative of a broader neo-liberal worldview that talks of inclusivity as a humane concern inspired by commitments to social justice and a pragmatic interest in preventing social unrest and a sense of insecurity said to be associated with excluding sections of the population from 'mainstream' activities. At the same time the declared policy intent of social inclusion is to reduce costs through the use of 'convenient' self service one-stop shops, the greater use of technology and automated services designed to 'improve efficiency'. In short, what DHS propose is to extend the New Public Management (NPM) rationalization project that has been in place now since the 1990s. It is an approach that has sponsored major and often detrimental changes to human services. Amongst other things this has seen the privatization of state services, their corporatization, the implementation of new 'accountability' and regulatory regimes such as 'quality auditing', and the introduction of 'evidence-based policy'.

Developments like these present a few challenging questions for 'education providers.' Are human service professionals, and specifically youth workers, to be educated with a view towards docilely complying with such arrangements, or should they be educated to think critically about the contexts in which they work? Are they to be educated to follow through with actions aligned with their thinking? Should students be encouraged to transform what is the increasingly recognized as deficient neo-liberal models of human service delivery? We propose that good 
youth work practice entails more than demonstrating instrumental rationality and officially and typically narrowly prescribed technical competencies. It also requires an ability and interest in shaping the habitus and policies that inform the youth sector. For this a decent university education is critical.

Unlike advocates of 'human capital' theory who talk about return of investment in education by way of lifetime earnings, we suggest the value of higher education lies in its capacity to develop critical reasoning and practical wisdom or what Aristotle called phronesis (Aristotle 1998). A good youth work university education should equip graduates with the interest and ability to figure out what is the right thing to do for the right reasons in each particular circumstance and then how to align their actions with that judgment (Schwartz and Sharpe 2010). We note that such capabilities are distinct from an approach to education and practice based on following rules or 'ticking boxes'. The capacity for value-rationality and moral judgment are also noticeably absent from competency based training and the lists of 'employability skills' employers and their interest groups expect of universities in graduating 'job-ready' practitioners (eg Australian Industry Skills Councils). We argue these capacities are critical if youth workers are to have the capacity needed to shape their own professional habitus and to have a worthwhile impact on policy and practice.

It is these observations that animate a number of questions about the state of youth work education which we explore in this article. While much of the material we draw on is Australian, we suggest there are sufficient commonalities between Australia and many other countries (ie England, Scotland, NZ) to make arguments and findings applicable to other jurisdictions. We note also the unprecedented international interest in strengthening the provision of youth work education. Our article aims to contribute to this project and associated debates with a focus on Australia (Commonwealth Secretariat 2012, Fusco 2012a, ProYouthWork America 2011). We write with the assumption that enlarging current levels of university-based youth work education is vital and detail the reasons for this later in the article. We ask: what is the status of youth work education in Australian universities? What factors affect supply and demand for youth work courses in higher education? What is the demand for youth work graduates in the relevant labour market? Finally, what reasons are there for investing in university youth work programs?

\section{The status of youth work education in Australian universities}

For well over forty years Australian government reports and independent research have identified the need for quality youth work education (Chew 1995; Hamilton-Smith and Brownell 1973; Maunders 1990; Szirom and Spartels 1995; Wright, 1995). The Australian Youth Affairs Coalition (AYAC) (2011a) also recently surveyed the youth sector asking what the minimum level of qualification should be to practice youth work. The overwhelming response was an 'undergraduate degree.' Yet despite these calls, moves to implement recommendations to extend the provision of university youth work programs have largely fallen on deaf ears.

In 2013, university youth work education is not available in a number of states and territories. In 2013, only five of Australia's 39 universities offered youth work degrees, degrees with youth work majors and double majors or double degrees that included youth work at an undergraduate or postgraduate level. These included the Australian Catholic University, Edith Cowan University, RMIT University, Victoria University and Southern Cross University. Tabor College, a religious private higher education provider, offers youth work degrees in South Australia and Victoria. The scarcity of youth work degrees has not been helped by the recent closure of programs and contraction of others. The University of Western Sydney closed its youth work degree in 2010 and the Australian Catholic University ceased offering its post-graduate Certificate in Human Services (Youth Work) in 2011. 
Australia now lags behind other comparable countries in providing university Youth Work education. In the UK for example, while youth work programs have been under threat, access to youth work in higher education has been widely available for some time (Holmes, 2007). This is despite the fact as Sercombe (2013) reported that the recent fee increases contributed to the closure of some university youth work courses across the region. In the US Fusco (2012b) reported a 900\% increase in university based youth work programs from 2008 to 2012. Likewise in Europe the European Commission and the Council of Europe have been working together since 1998 to improve the training of youth workers in order to guarantee the quality of youth work (Council of the European Union 2010; Mitter 1999). In short, compared with other similar jurisdictions Australia continues to fall behind.

Australian youth work programs in higher education face a precarious future. One damaging influence has been a de-valuing of youth work education within the university and a more general lack of high profile in the community (White 2011). In 2010 the Australian Office for Learning and Teaching (formally the Australian Learning and Teaching Council) project examining youth work education also reported that many of the youth work university programs were under pressure to make financial savings (unauthored 2010). This situation is also partly explained by the absence of a strong professional association and associated accreditation requirements, which can play a protective role. The absence of a strong tradition that sees youth workers themselves building their own body of knowledge has also been sorely missed (cf medicine, nursing, psychology etc). A mix of a strident anti-intellectualism that has characterized the field has also not been conducive to youth work education in higher education (Denholm and Ling 1990; Ewen 1981, p.101).

In comparison to university youth work education we see an abundance of lower level vocational education and training (VET) youth work certificates or diplomas. Currently there are dozens of VET providers across Australia delivering the Certificate IV in Youth Work and the Diploma in Youth Work. The Community Services and Health Industry Skills Council (2012) reported that for 2010 there were 2,243 enrolments in the Certificate IV and 643 enrolments in the Diploma.

In spite of this trend, we argue there are good reasons why youth work education should be located in the university. To begin, youth work training in the VET sector has come under sustained criticism for almost fifteen years (Broadbent 1998; Name deleted to maintain the integrity of the review process). According to Corney and Broadbent (2007) the integrity of VET youth work training had been undermined by successive problematic training package reviews. Secondly inadequate regulation of youth work training in the vocational training sector reinforces doubts that it can provide the kind of quality training needed to build an appropriately qualified workforce.

Thirdly, while the 'competency based' training delivered by VET plays an important role in educating practitioners, on its own this training is not enough. The kind of competency based training and assessment provided by VET can produce proficient technicians who possess beginning level capabilities, and can follow and apply instructions. However this focus on developing students' instrumental rationality or 'know how' does not go far enough in providing learning opportunities that cultivate good practice. It provides for beginning level learning that needs further development - ideally in higher education (Kinsella and Pitman 2012). We argue that universities are best equipped to ensure graduates not only have technical competencies, but also have reflexive and critical capacities needed to be expert, a graduate attribute that entails having a regard for 'good or bad' when working out what action is best for a particular situation (Dreyfus and Dreyfus 1986). A good university education nurtures in students their capacity to draw on, and in the right balance, three intellectual virtues required for good practice, namely, techne, episteme and phronesis. It entails learning how to go beyond the analytic, scientific 
knowledge (episteme) and the technical knowledge or know-how (techne) and involves the capacity to make judgments in the manner of a virtuoso social and political actor (Flyvbjerg 2001 p.2)

Fourthly regulatory bodies have raised concerns about the quality of VET training (Productivity Commission, 2011a, 2011b, 2011c, 2011d). Since 2009 successive State governments in places like Victoria have changed VET funding arrangement, to increase competition between public and private providers. This reform, which is likely to be implemented nation wide, benefits private registered training organizations at the expense of the public TAFE sector, and is geared towards driving costs down in ways that further seriously compromises the quality of youth work training delivered in the VET sector (Hall and Preiss, 2012).

Fifthly, VET credentials are increasingly less attractive to students as they have become more expensive. Additionally increasing numbers of employers in the youth sector expect recruits with at least a bachelor degree-level education. As Skills Australia chief executive Robin Shreeve reiterated, increasingly university qualifications are required to get a decent paying job, and if youth work is to have a future, practitioners need a higher education (Rowbotham 2011). Finally, if youth work education is to be predominantly based in VET then we would see little if any research or knowledge production, something that is critical for fostering a professional identity and a specialized knowledge base.

\section{The higher education policy context}

Currently we operate in a policy context where the notion of education as a social good is seldom taken seriously (Nussbaum 2010). Amongst other things, this is a consequence of policy-makers embracing the neo-liberal idea that individual utility maximizing effect through market mechanisms will shape the future of higher education. It is a policy shift affirmed by the national government's own 'Bradley Review' of Australian Higher Education (Bradley, Noonan, Nugent and Scales 2008). Despite popular and official expressions of concern about skills shortages and support for the rhetoric of building a 'clever country', the Bradley Review recommended moving to a demand-driven system. This was implemented in 2012 when the Federal government removed 'caps' from government funded university places, signaling that labour market demands or social need would no longer play a part in shaping the profile of higher education enrolments. ${ }^{1}$ The effect of this policy shift is that student demand will increasingly determine which programs are offered: low demand programs will be closed down while high demand programs will expand. This is a problem for youth work because - as we mentioned above - it is a sector that has not enjoyed attractive wages and conditions or the benefits of high status in the community. This understandably effects demands for programs.

Arguably and in the context of what is an 'individualized society' increasing numbers of students have pursued more remunerative career paths, in part to help repay their education fee debt. We note we have seen a steady growth in higher status, high demand programs. Law schools have proliferated with an increase from 12 law schools in 1984 to 32 by 2012 (Thornton 2012, p.6). Paralleling this has been a steady growth of business schools and to a lesser extent of health science programs. For example, from 2001 to 2011 in all areas of health, student applications rose by $78 \%$ with the highest in the highest paying area ie, dentistry (502.1\%) (Group of Eight 2012). Amongst other things this has the effect of seriously reducing the ability of universities to cross-subsidize smaller courses as they once did (Group of Eight 2012, p.4). This matters for youth work because historically the practice of cross-subsidization within the university has been

\footnotetext{
${ }^{1}$ We note that medicine is exempt from this new demand driven system. Health professionals more generally are not.
} 
critical to programs such as youth work which tended not to attract students interested in high status high paying jobs.

More generally government funding for universities has steadily declined to a point where it does not meet the costs of essential activities like teaching and research (Lamox-Smith, Watson and Webester 2011). Data from the Higher Education Base Funding Review Final Report 'found' government funding rates were lower than costs. Indeed the 'real value' of the Commonwealth contribution to base funding provided to universities per student, '.. fell sharply after the mid1990s and, while it has increased since 2003, it remains well below the 1994 levels' (LomaxSmith, et.al 2011 pp.3-4). Moreover, despite its commitment to an 'Education Revolution' the Gillard Labor government has not increased base funding for universities following the Review's recommendations for more investment and for increases in the average level of base funding per student place.

In the prevailing context fiscal interests have priority over other interests (eg. social goods). It is a situation which threatens the quality and indeed the continuation of youth work programs because those programs tend to be small, and in the new 'demand driven' university system find it difficult to 'compete' with other higher demand 'more attractive' high status programs. All this effects what are described as program 'viabilities' (eg., school entry scores, student staff ratios, etc.) which in turn make youth work programs vulnerable.

We now turn to the question of labour market demands for youth work graduates.

\section{The demand and supply of youth work graduates}

One difficulty the youth sector and labour market researchers face when trying to answer this question is that little if any analysis has been done on the demand and supply of youth work graduates in Australia. To establish a beginning sense of what the situation is we used electronic data bases like ProQuest 5000, JSTOR and OCLC ECO collections on-line to search for 'youth work education', 'workforce supply and demand'. More general searchers were also carried out using Google and the websites of relevant government departments.

What we found was that while a demand exists for qualified youth workers, it is difficult to quantify that demand precisely. This difficulty reflects problems with the nomenclature used by researchers. One problem is the occupational category 'youth work' which is typically not used when labour market data is being collected. It is usually incorporated in other sector profiles such as human services, child protection, juvenile justice, community services and 'other social assistance services' (eg., Australian Government 2011; Community Services and Health Industry Skills Council, 2012; Healy and Lonne 2010; Martin and Healy, 2010). This means that clear and precise figures on demands, shortages and associated educational needs are not available.

In 2008 the Department of Education, Employment and Workplace Relations (DEEWR) (2008) carried out an occupational survey on 'Youth Workers' and youth work received a 'no shortage' labour market rating. Paradoxically, at the same time the survey reported increasing demand for youth workers and a lack of qualifications and experience as the main reasons employers gave for considering job applicants unsuitable. Subsequently DEEWR decided to abandon reference to 'youth work' in future labour market surveys and collapsed it into the generic 'welfare worker' and 'welfare support worker' categories (DEEWR 2011a; DEEWR nd). Given that DEEWR no longer uses the youth work category, they cannot report supply and demand issues in respect of youth work graduates. This highlights the issue of status and professional recognition and the need to use 'youth work' as an occupational category. It is needed if we are to get specific demand and supply analysis of youth workers. 
To get some sense of the demand for graduate and to overcome this hurdle, we have extrapolated from the material that is available. Assembling the current official research enables us to infer that there is likely to be a shortage of youth work graduates in Australia. Name deleted to maintain the integrity of the review process surveyed human service and youth sector workforce audits and reported critical skill shortages in the youth sector (see also; Community Services and Health Industry Skills Council 2012, PricewaterhouseCoopers and The Centre for Social Impact 2012). Service providers reported increasing difficulty in attracting and retaining qualified, skilled and experienced staff. Problems with recruitment combined with high attrition rates contributed to service shortfalls, escalating waiting lists and high levels of unmet need. At the same time there was a greater than ever demands for youth services, increasing complexity in youth work and mounting workloads. AYAC (2011b) reiterated that youth work employers across Australia faced difficulties recruiting and retaining high quality, well-trained youth workers. Martin and Healy (2010, p.204) also reported that employers in child protection and juvenile justice sectors, which they argue include youth support workers and youth workers, 'faced a substantial recruitment task.' That included the task of replacing 'at least one quarter of their employees every year'. They added there is 'fairly limited excess labour capacity' in the workforces (p. 208). Similarly DEEWR (2012a, 2012b) projected that 'health care and social assistance' industries, which include youth work, will to grow more than twice the average rate of all industries and contribute one in four of all new jobs over the five years to 2015-16. This also indicates increased demand for youth work.

The demand is also suggested for the recent period in a 2011 DEEWR report on National skill shortage in the category 'Welfare Worker', which is the occupational category that includes youth workers (DEEWR 2011b). Similarly the Australian Government (2011) listed 'Welfare Support Workers', (again encompassing youth work), as an occupation difficult to fill. The occupational report from DEEWR (2011a) for 'Welfare Worker' also found that: 'Employers were generally seeking tertiary qualified and experienced welfare workers'. Moreover, the 'majority of employers surveyed reported difficulty recruiting qualified and experienced welfare workers' (DEEWR 2011a). The report found, 'Unsuitable applicants generally lacked qualifications and/or experience', and 'This included applicants with Certificate level qualifications, as Diploma or Degree qualifications were required for the vast majority of positions' (DEEWR 2011a).

In 2012, youth work was listed as an occupation for skilled migration on a number of occupations lists (Acacia Immigration Australia 2012). Likewise the Australian Visa Bureau (2012) reported that, 'If your profession is Youth Worker...then you are currently in demand by employers in Australia'. The government recruitment of youth workers from overseas implies there is a demand and insufficient supply to meet that requirement.

Available data indicates the supply of youth work graduates in Australia is not meeting workforce needs. For the reasons mentioned above, a labour market analysis that includes technical modeling projections which specify youth work is needed urgently. What is also needed is an analysis of the implications of that data for universities who are required to produce the graduates.

\section{Reasons for investment in university youth work programs}

It seems clear that workforce audits and official reports also indicate a need for more tertiary qualified youth workers. We suggest that an approach of targeted investments and incentives is needed for the education of youth workers. 
It is worth noting that governments in Australia, like elsewhere, have been prepared to invest steadily to increase enrolments and improve retention in some occupational areas. Since 2009 eg., teaching and nursing received large increases in funding, plus incentives for graduates in those areas were provided (They had their compulsory Higher Education Loan Program (HELP) debt repayments significantly reduced) (Australian Government 2009). Similarly the Federal Government recently implemented a comprehensive suite of new measures to train and retain a qualified early childhood education workforce which included the allocation of new Commonwealth supported higher education places, recognition of prior learning packages, and HELP benefits (DEEWR 2011c). Targeted funding to build the capacity of the mental health workforce also came in the form of funded higher education places, scholarships and curriculum development (Council of Australian Governments 2006). Additionally the Federal government committed $\$ 1.2$ billion to secure an appropriately skilled and well qualified aged care workforce (Commonwealth of Australia 2012). Likewise due to the need for a national, coordinated approach to health workforce planning in 2009 the Council of Australian Governments established a new statutory authority, Health Workforce Australia, (Health Workforce Australia nd). Clearly the connection between education and the workforce planning has not been lost, what seems to be missing is recognition of the need for young people to have access to quality professional youth work practice.

Quality youth work education enhances the well-being of young people by improving professional practice and contributing towards building a viable youth sector. We work on the assumption that nurturing the young person to enhance their life and improve prospects for a flourishing life is central to youth work. This rests on an interest in valuing the young person for their own sake rather than a means to an end (ie investment in human capital). It rests on a capacity to identify what a young person is good at along with an interest in drawing out and developing those abilities, while at the same time working to develop one's own capacity to be a good practitioner. This requires qualities like self control, critical thinking, a commitment to an ethics of care, along with an interest in and ability to access the requisite knowledge and skills to do the job well.

Youth work is a professional practice informed by the idea that what is happening in the lives of young people can have a major impact, for better or worse, on their immediate and future lives. The rationale for investing in the education of practitioners is that it enhances the prospect that young people will have flourishing lives now and as they grow. And while youth work is not just for young people who find themselves in trouble, it certainly can and does ameliorate some of the negative effects of social problems like poverty, illicit substance abuse, homelessness and sexual abuse.

Young people also move in and out of difficulty and for this reason the right degree of intervention at the right time can prevent the exacerbation of problems. Professional discretion and the capacity to be able to read a particular situation, to see what is going on and provide assistance before matters deteriorate is a critical youth work capacity. There is also an argument for investment in youth work education that calls on strategic even 'economistic' arguments. Using this framework we argue that failure to invest in youth work in higher education is short sighted and does nothing to avert problems 'down the track' which could have been prevented as well as costly lost opportunities.

Investment in youth work education is critical if some of the government's key policy objectives are to be achieved. If the Commonwealth government is serious about 'providing young Australians with the support they need to succeed' and building the capacity of the youth sector then measures are needed to support building an effective workforce (Australian Government 2010). Investing in youth work education would also go a long way towards the supporting national initiatives like the Youth Connections Program which aims to support young people 
gain a year 12 or equivalent level education. It is a program that is more likely to succeed with young people identified as being 'at risk' if they are supported by qualified youth workers (DEEWR 2011d). The same case can be made about governments' targets for increasing student participation in higher education - particularly in respect to those from low socio-economic status backgrounds (Australian Government 2009). Increasing numbers of university youth work graduates are recruited by schools and some universities to assist in this regard. Reforms to and significant investment in the National School Chaplaincy and Student Welfare Program has also increased demand for high-quality youth work training (DEEWR 2012c).

Investment in youth work education is also aligned with moves to professionalise youth work. The states of Victoria and Western Australia are leading the push with the establishment of professional associations and it is not surprising that in these jurisdictions university youth work programs are on offer. While VET certificates provide a good start, we argue that on their own they are not enough. If we want expert practitioners able and willing to play an active role in shaping the policy and practice landscape it is critical that they be educated to critically assess what is happening and to act in ways oriented towards social goods as opposed to an exclusively competency based approach to practice.

\section{Conclusion}

In spite of the calls for improved professional service provision for young people, youth work in Australia has made little progress in building a qualified workforce. We have not yet seen a professional culture emerge or the organizational supports like those enjoyed by teachers, nurses, early childhood educators or various health professionals. Compared to the investments made in these industries, the financial commitment made to building the youth work workforce has been miniscule. It is a situation that is likely to get worse given the context of the student demand-led higher education policy model.

We suggest that one way of encouraging university qualifications as a required standard is to regulate the sector with minimal educational credentials equivalent to those required in similar professions. Currently the credentials required are either no formal qualification or a TAFE certificate. This in conjunction with low wages, insecure employment, unclear career paths and low status is not conducive to building a strong sector or improving the prospect for programs in higher education. We argued that while competency based training of the kind provided in TAFE offers an excellent beginning level training, on its own it is not enough. It needs to be complemented by education, ideally offered in a university program designed so as to provide learning experiences that equip graduates with the ability to make good judgment and to act according to those judgments.

\section{References}

Acacia Immigration Australia. (2012). Youth Worker - ANZSCO 411716m [online]. Available from: http://www.acacia-au.com/anzsco/411716.php [Accessed 1 June 2012].

Aristotle. (1998). The Nichomachean Ethics (Trans. And Intro. D. Ross). Oxford: Oxford University Press.

Australian Government. (2011). Skills info: Health care and social assistance [online]. http://skillsinfo.gov.au/sites/default/files/documents/healthcareandsocialassistancereport2011.pdf [Accessed 1 June 2012]. 
Australian Government. (2010). National Strategy for Young Australians [online]. http://youth.gov.au/bodyImage/Documents/NatStrat.pdf [Accessed 1 May 2102].

Australian Government. (2009). Transforming Australia's Higher Education System. Canberra: Commonwealth of Australia.

Australian Visa Bureau. (2012). Youth Worker Australia [online]. http://www.visabureau.com/australia/anzsco/jobs/youth-worker-australia.aspx [Accessed 1 June 2012].

Australian Youth Affairs Coalition. (2011a). Future focused: Youth Work in Australia: Reflections and Aspirations. Surry Hills, New South Wales: Australian Youth Affairs Coalition.

Australian Youth Affairs Coalition. (2011b). Submission in response to Community Services and Health Industry Skills Council (CS\&HISC) Environmental Scan (EScan) 2012. Surry Hills, New South Wales: Australian Youth Affairs Coalition.

Bradley, D., Noonan, P., Nugent, H. \& Scales, B. (2008). Review of Australian Higher Education: Final Report. Canberra: Australian Government.

Broadbent, R. (1998). National vocational training policy and youth work training. Youth Studies Australia, 17 (2), 11-17.

Chew, P. (1995). Report of the ministerial review of the training of youth workers in Victoria. Melbourne: Government of Victoria.

Commonwealth of Australia. (2012). Living longer. Living better. Canberra: Australian Government.

Commonwealth Secretariat. (2012). Conference on education and training of youth workers: CETYW 2013 [online]. http://ccetyw.cyponline.org/index.html [Accessed 4 March 2013].

Community Services and Health Industry Skills Council. (2012). Environmental scan 2012. Strawberry Hills, New South Wales: Community Services and Health Industry Skills Council.

Corney, T. \& Broadbent, R. (2007). Youth work training package review: More of the same or radical rationalization?. Youth Studies Australia, 26 (3), 36-43.

Council of Australian Governments. (2006). National Action Plan on Mental Health 2006-2011 [online]. http://www.coag.gov.au/coag_meeting_outcomes/2006-0714/docs/nap_mental_health.pdf [Accessed 1 May 2012].

Council of the European Union. (2010). Resolution of the Council and of the representatives of the governments of the member states, meeting within the Council, on youth work [online]. http://www.ycni.org/downloads/euro_international/European-Resolution.pdf [Accessed 7 March 2012].

Denholm, C. \& Ling, P. (1990). Education and training in youth work. Youth Studies Australia, 9 (2), 24-27.

Department of Education, Employment and Workplace Relations. (2012a). Industry employment projections: 
http://www.deewr.gov.au/LMIP/default.aspx?LMIP/Publications/IndustryEmploymentProjection s [Accessed 1 June 2012].

Department of Education, Employment and Workplace Relations. (2012b). Australian jobs. Canberra: Australian Government.

Department of Education, Employment and Workplace Relations. (2012c). National school chaplaincy and student welfare program overview [online]. http://www.deewr.gov.au/Schooling/NSCSWP/Pages/NSCSWP_Overview.aspx [Accessed 1 June 2012].

Department of Education, Employment and Workplace Relations. (2011a). ANZSCO 2726-13 Welfare worker

[online]

http://www.deewr.gov.au/Employment/LMI/SkillShortages/Documents/Nat_Occupationalreport/ WelfareWorker272613.pdf [Accessed 1 June 2012].

Department of Education, Employment and Workplace Relations. (2011b). Skill Shortage List Australia [online] http://www.deewr.gov.au/Employment/LMI/SkillShortages/Documents/SSL_AUS.pdf [Accessed 1 June 2012].

Department of Education, Employment and Workplace Relations. (2011c). Early Childhood Workforce [online] http://www.deewr.gov.au/earlychildhood/policy_agenda/earlychildhoodworkforce/Pages/home.a spx [Accessed 1 May 2012].

Department of Education, Employment and Workplace Relations. (2011d). Youth attainment and transitions home [online]. http://www.deewr.gov.au/youth/YouthAttainmentandTransitions/Pages/Home.aspx [Accessed 1 May 2012].

Department of Education Employment and Workplace Relations. (2008). Youth Worker [online]. http://www.workplace.gov.au/NR/rdonlyres/E19D5DFA-7EFE-4B40-863B-

F7E42D1BCC67/0/411716AUSYouthWorkerschkd.pdf [Accessed 1 June 2012].

Department of Education, Employment and Workplace Relations. (nd). Job outlook: Welfare Support Workers [online]. http://joboutlook.gov.au/pages/occupation.aspx?code=4117 [Accessed 1 June 2012].

Department of Human Services. (2011). Service Delivery Reform: Transforming Government Service Delivery. Canberra: Department of Human Services.

Dreyfus, H. \& Dreyfus, S. (1986). Mind over machine: The power of human intuition and expertise in the era of the computer. New York: Free Press.

Ewen, J. (1981). The education and training of youth workers in Australia: A discussion paper. Canberra: Office of Youth Affairs, Department of Employment and Youth Affairs.

Flyvbjerg, B. (2001). Making social science matter: Why social inquiry fails and how it can succeed again. Cambridge: Cambridge University Press.

Fusco, D. (ed.) (2012a). Advancing youth work: Current trends, critical questions. New York: Routledge. 
Fusco, D. (2012b). Working in youth service organisation: The sphere of professional education. St. Paul, MN: University of Minnesota.

Group of Eight. (2012). Policy Note: Demand for Higher Education, by field [online]. http://www.go8.edu.au/_documents/go8-policyanalysis/2012/go8policynote5_demandforhe_final.pdf [Accessed 1 June 2012].

Hall, B. \& Preiss, B. (2012). Holmesglen TAFE 'in peril'. The Age, 18 May [online]. http://www.theage.com.au/national/education/holmesglen-tafe-in-peril-20120517-1ytnq.html [Accessed 19 May 2012].

Hamilton-Smith, E. \& Brownell, D. (1973). Youth workers and their education. Carlton South, Victoria: Youth Workers Association of Victoria.

Health Workforce Australia. (nd). Welcome to Health Workforce Australia [online]. http://www.hwa.gov.au/ [Accessed 1 May 2012].

Healy, K. \& Lonne, B. (2010). The social work and human services workforce: Report from a national study of education, training and workforce needs. Strawberry Hills, New South Wales: Australian Learning and Teaching Council.

Holmes, J. (2007). Introduction: Youth and community work qualifying courses - living with the tensions?. Youth and Policy, 97 \& 98, 5-11.

Kinsella, E.A. \& Pitman, A., (eds.) (2012). Phronesis and professional knowledge: Practical wisdom in the professions. Rotterdam: Sense Publishers,.

Lomax-Smith, J., Watson, L. \& Webster, B. (2011). Higher education base funding review: Final report [online]. http://www.deewr.gov.au/HigherEducation/Policy/BaseReview/Documents/HigherEd_FundingR eviewReport.pdf [Accessed 1 May 2012].

Martin, B. \& Healy, J. (2010). Who works in community services? A profile of Australian workforces in child protection, juvenile justice, disability services and general community services. Flinders University, Adelaide: National Institute of Labour Studies.

Maunders, D. (1990). Professional education for youth work: Expanding field or anachronism?. Paper presented at the Australian Association for Educational Research Conference, Sydney, 2730 November.

Mitter, S. (1999). The Partnership Between the European Commission and the Council of Europe in the Field of Youth. Coyote, 0 (July 1999).

Nussbaum, M. (2010). Not for profit: Why democracy needs the humanities. Princeton, NJ: Princeton University Press.

PricewaterhouseCoopers and The Centre for Social Impact. (2012). PwC-CSI Community Index: Not-for-profit sector biannual survey. Melbourne: PricewaterhouseCoopers.

Productivity Commission. (2011a). Disability Care and Support, Report no. 54. Canberra: Commonwealth of Australia. 
Productivity Commission. (2011b). Caring for Older Australians, Draft Inquiry Report. Canberra: Commonwealth of Australia.

Productivity Commission. (2011c). Early Child Development Workforce, Draft Research Report June. Canberra: Commonwealth of Australia.

Productivity Commission. (2011d). Vocational Education and Training Workforce, Research Report, May. Canberra: Commonwealth of Australia.

ProYouthWork America. (2011). Youth work practice: A status report on professionalisation and expert opinion about the future of the field. Charlotte, VT : New England Network for Child, Youth and Family Services.

Rowbotham, J. (2011). TAFE diplomas losing their vocation. The Australian, 13 April [online]. http://www.theaustralian.com.au/higher-education/tafe-diplomas-losing-their-vocation/storye6frgcjx-1226038131581 [Accessed 1 May 2012].

Schwartz, B. \& Sharpe, K. (2011). Practical wisdom: The right way to do the right thing. New York: Riverhead books.

Sercombe, H. (2013). What will youth work look like in 2013?. The Ultimate Youth Worker. 8 January [online]. http:/ultimateyouthworker.blogspot.com.au/2013/01/what-will-youth-worklook-like-in-2013.html [Accessed 4 March 2013].

Szirom, T. \& Spartels, D. (1995). A framework for practice based training in youth work: Summary. Fairfield, Victoria: Social and Community Services Training Board.

Thornton, M. (2012). Privatising the Public University: The Case of Law. Oxon, UK: Routledge.

Unauthored. (2010). Australian youth work education: Curriculum renewal and a model for sustainability for niche professions: Australian university youth work education in 2010: Context. Canberra: Australian Learning and Teaching Council.

White, R. (2011). Youth work in a changing climate. Presentation at the Queensland Youth Affairs Conference, Brisbane, 20-21 July [online]. http://www.yanq.org.au/qyac/3316conference-presentation-youth-work-in-a-changing-climate [Accessed 1 May 2012].

Wright, I. (1995). Submission to the review of training of youth workers. Victoria: Victorian Country Youth Services Inc. 